\title{
ARTICLES
}

Submitted 07.31.2018. Approved 06.04.2019

Evaluated through a double-blind review process. Scientific Editor: Yeda Swirski de Souza

Original version

DOI: http://dx.doi.org/10.1590/So034-759020190403

\section{CONFIGURATIONS OF KNOWLEDGE-INTENSIVE ENTREPRENEURIAL ECOSYSTEMS}

\author{
Configurações de ecossistemas de empreendedorismo intensivo em conhecimento \\ Configuraciones de ecosistemas de emprendimiento intensivo en conocimiento
}

\begin{abstract}
ANDRE CHERUBINI ALVES ${ }^{12}$ andre.alves82@gmail.com ORCID: 0000-0002-4222-5334
\end{abstract}

\section{BRUNO FISCHER ${ }^{3}$}

bfischer@unicamp.br

ORCID: 0000-0003-3878-9097

\section{NICHOLAS SPYRIDON VONORTAS}

vonortas@gwu.edu

ORCID: 0000-0002-6745-4926

\section{SÉRGIO ROBLES REIS DE QUEIROZ ${ }^{1}$}

squeiroz@ige.unicamp.br ORCID: 0000-0002-6534-9022

${ }^{1}$ Universidade Estadual de Campinas, Departamento de Política Científica e Tecnológica, Campinas, SP, Brazil

${ }^{2}$ Fundação Getulio Vargas, Escola de Administração de Empresas de São Paulo, São Paulo, SP, Brazil

3Universidade Estadual de Campinas, Faculdade de Ciências Aplicadas, Limeira, SP, Brazil

4The George Washington University, Institute for International Science and Technology Policy, Department of Economics, Washington, DC, United Stated of America

\begin{abstract}
The dominant discourse on Entrepreneurial Ecosystems (EE) remains focused on the profile of a handful of successful locations. This has hindered a deeper comprehension of the economic mechanisms that shape evolutionary trends in entrepreneurial activity and how they operate in distinct places. We propose that EE have regularities, but they can also assume different configurations, i.e., varying combinations of influential dimensions. Through fuzzy set qualitative comparative analysis, we address this issue with data from the State of São Paulo, Brazil. This research focuses on five EE dimensions: Science \& Technology, Human Capital, Market Dynamics, Business Dynamics, and Infrastructure. Findings point at the heterogeneous nature of EE distributed in three different paths. While configurations' vary in terms of causal conditions, research universities, knowledge-intensive jobs and wider credit operations are core-causal conditions. Proximity to the main economic hub appears as a key differentiator among ecosystems.
\end{abstract}

KEYWORDS | Entrepreneurial ecosystems, knowledge-intensive entrepreneurship, qualitative comparative analysis, configurations, geography of innovation.

\section{RESUMO}

O discurso dominante sobre os ecossistemas de empreendedorismo (EE) enfatiza o perfil de algumas localidades com reconhecido histórico de sucesso. Isso tem dificultado uma compreensão mais profunda dos mecanismos econômicos que moldam as tendências evolutivas na atividade empreendedora e como elas operam em lugares distintos. Nós propomos que esses ecossistemas possuem regularidades, mas elas também podem assumir diferentes configurações. Por meio de técnicas de fuzzy-set Qualitative Comparative Analysis (QCA), abordamos essa questão com dados do estado de São Paulo. Esta pesquisa concentra-se em cinco dimensões dos ecossistemas de empreendedorismo: ciência e tecnologia, capital humano, dinâmica de mercado, dinâmica dos negócios e infraestrutura. Os resultados apontam para a natureza relativamente heterogênea dos ecossistemas. Não obstante, as universidades de pesquisa, a intensidade de empregos intensivos em conhecimento e a disponibilidade de crédito são condições fundamentais. A proximidade do principal centro econômico aparece como um diferencial importante entre os ecossistemas.

PALAVRAS-CHAVE / Ecossistemas de empreendedorismo, empreendedorismo intensivo em conhecimento, qualitative comparative analysis, configurações, geografia da inovação.

\section{RESUMEN}

El discurso dominante respecto a los Ecosistemas de emprendimiento (EE) pone énfasis en el perfil de algunas localidades con reconocido historial de éxito. Esto ha dificultado una comprensión más profunda de los mecanismos económicos que moldean las tendencias evolutivas en la actividad emprendedora y cómo ellas operan en lugares distintos. Partimos de la proposición de que estos ecosistemas tienen regularidades, pero también pueden asumir diferentes configuraciones. A través de técnicas de fuzzy-set Qualitative Comparative Analysis, abordamos el caso del Estado de São Paulo, Brasil, enfocando cinco dimensiones de los Ecosistemas de emprendimiento: Ciencia y Tecnología, Capital Humano, Dinámica de Mercado, Dinámica de Negocios e Infraestructura. Los resultados apuntan a la naturaleza relativamente heterogénea de los ecosistemas. No obstante, las universidades de investigación, la intensidad de empleos intensivos en conocimiento y la disponibilidad de crédito son condiciones fundamentales. La proximidad del principal centro económico representa un aspecto diferencial importante entre los ecosistemas.

PALABRAS CLAVE I Ecosistemas de emprendimiento, emprendimientos intensivos en conocimiento, qua litative comparative analysis, configuraciones, geografía de la innovación. 


\section{INTRODUCTION}

Knowledge-intensive entrepreneurship (KIE) refers to a phenomenon that drives economic competitiveness and innovation capabilities (Ács, Autio, \& Szerb, 2014). It has, however, received relatively little attention in studies related to the approaches of innovation systems. The influence of context upon entrepreneurial activity is still often ignored in favor of a focus on individuals and firms (Borissenko \& Boschma, 2016; Stam, 2015). As a result, we are still far from developing a thorough understanding of issues related to the emergence of new technology-based companies and its systemic determinants (Audretsch, 2012).

It is clear that KIE is unevenly distributed across territories, a function of heterogeneous endowments in terms of knowledge, institutions, resources, and demand (Isaksen \& Trippl, 2017). As a consequence, we observe a spiky geography of economic activities (Florida, 2005). In addition, evidence suggests that the impacts of entrepreneurial activity are mainly felt at the regional level (Ács \& Armington, 2004), placing Entrepreneurial Ecosystems (EEs) as a key subject of interest for researchers and policymakers (Audretsch \& Belitski, 2017; Borissenko \& Boschma, 2016).

The fact that KIE is deeply embedded in local contexts (Alvedalen \& Boschma, 2017) poses challenges for analysts and policymakers, as one-size-fits-all initiatives and analytical models may be deemed inappropriate for most locations - although the dominant discourse remains focused on the profile of a handful of successful EEs (Nicotra, Romano, Giudice, \& Schillaci, 2018; Stam, 2015). Accordingly, the economic mechanisms that shape evolutionary trends in entrepreneurship are not linear, and they operate differently in distinct locations (Ács, Stam, Audretsch \& O’Connor, 2017; Brown \& Mason, 2017; Boschma \& Martin, 2010).

Thus, a mechanistic approach to entrepreneurial ecosystems (EEs) - based on an input-output logic - is likely to ignore the context-specific traits of regions and their respective interactions (Feldman, 2001). In this article, we propose that entrepreneurial ecosystems can have regularities, but they can also assume different configurations, i.e., varying combinations of influential dimensions that may generate similar outcomes in terms of entrepreneurial intensity. This is a function of the distinct evolutionary path of each location. Our guiding research questions can be stated as follows: Are there different configurations of vectors of interest that shape successful entrepreneurial ecosystems? What are the key "ingredients" of these combinations? Drawing from different strands of literature addressing the dynamics of business locations, we examine a broad set of variables in order to identify the different foundational patterns behind ecosystems of entrepreneurship.
As a concrete case, we assess the state of São Paulo, Brazil. We address KIE through data from Pesquisa Inovativa em Pequenas Empresas (Innovative Research in Small Business [PIPE]) projects, a program funded by Fundação de Amparo à Pesquisa do Estado de São Paulo (São Paulo Research Foundation [FAPESP]) that supports innovative initiatives in small enterprises. Our goal is to develop further knowledge on the evolutionary geography of innovation and entrepreneurship in the context of a developing country, acknowledging the substantial discrepancies that these countries present relative to developed economies when it comes to the geography of entrepreneurship (Crescenzi \& Rodríguez-Pose, 2012).

The empirical method applied is Qualitative Comparative Analysis (QCA) with fuzzy sets. We assessed data from a sample of 299 cities in the state of São Paulo. The analytical exercise focused on five dimensions as causal conditions for the emergence of entrepreneurial ecosystems, namely: science and technology, human capital, market dynamics, business dynamics, and infrastructure. Our findings present distinct general paths across different configurational solutions, suggesting the existence of heterogeneous patterns in entrepreneurial ecosystems. Nonetheless, a common core is perceived across the different configurations, mainly involving the science and technology environment, the availability of human capital, and local market dynamics.

The article is structured as follows: we begin with the conceptual background of our assessment, as well as our proposal of a workable analytical model for the case of the state of São Paulo. After, we discuss the state of the literature and the need for a more flexible comprehension of the configurations of entrepreneurial ecosystems. We then outline the method and data used in our approach and empirical findings. Lastly we offer some concluding remarks, implications, and avenues for future research.

\section{Knowledge-intensive entrepreneurial ecosystems: Conceptual background}

Regions differ in their propensity to establish knowledge-intensive entrepreneurial activity (Florida, 2005). The resulting patterns reinforce themselves over time, as geographic proximity functions as a fundamental vector for knowledge exchange (Alvedalen \& Boschma, 2017). These conditions put significant emphasis on local-level context as a determinant for KIE emergence, moving the analytical target beyond the mere understanding of firm-level capabilities (Mason \& Brown, 2014; Ács et al., 2014; Audretsch \& Belitski, 2017).

It is by acknowledging these features of the socioeconomic environment that the Entrepreneurial Ecosystems concept has 
gained ground in recent years. EEs are said to represent a "set of interconnected entrepreneurial actors, entrepreneurial organizations, institutions and entrepreneurial processes which formally and informally coalesce to connect, mediate and govern the performance within the local entrepreneurial environment" (Mason \& Brown, 2014; p. 5). The underlying rationale of entrepreneurial ecosystems is focused on interactions between agents, tangible and intangible factors of production, and how these vectors translate locally into entrepreneurship (Ács et al., 2017; Nicotra et al., 2018).

Because of its (eco)systemic character, the productivity of these geographical units is affected by the performance of any of their components (Ács et al., 2014). By productivity we understand what Radosevic and Yoruk (2013) call "entrepreneurial propensity," i.e., local capacity to generate and exploit innovation-oriented opportunities through the actions of entrepreneurs.

\section{Figure 1. Knowledge-Intensive Entrepreneurial Ecosystem}

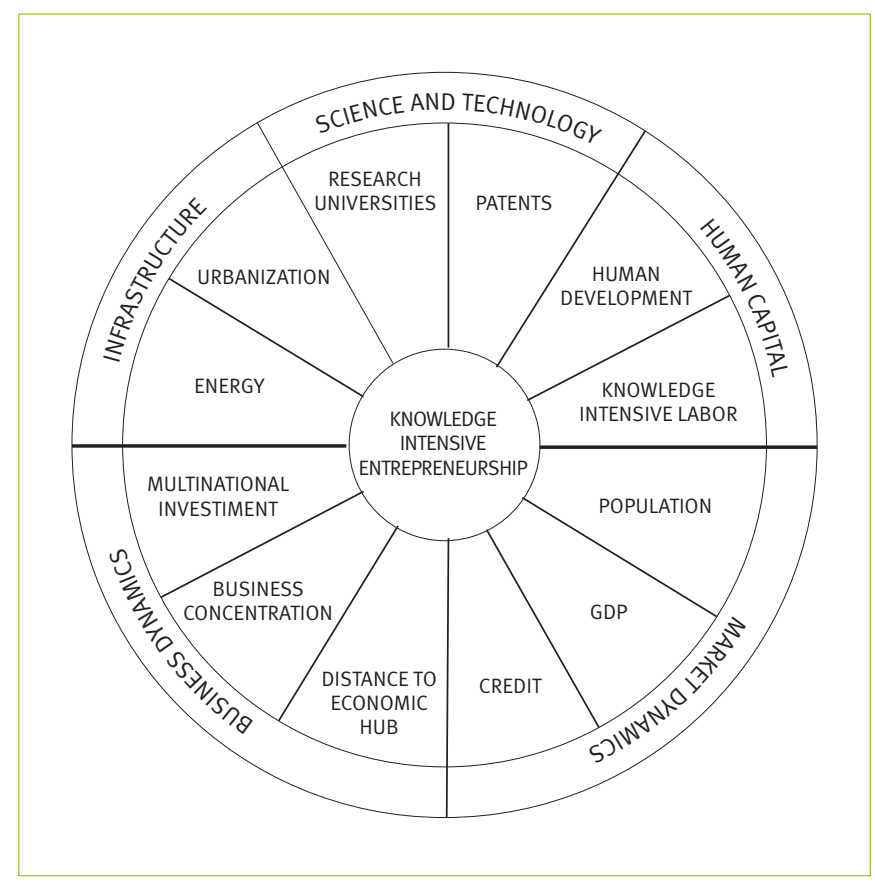

Source: Adapted from Isenberg (2010), Mason and Brown (2014), and Stam (2015).

Based on this literature, and with particular emphasis on the works of Isenberg (2010), Mason and Brown (2014), and Stam (2015), we offer a workable model of the entrepreneurial ecosystem concept (Figure 1). Our adaptation follows the basic principles contained in existing frameworks, thus contemplating issues associated to infrastructure, human capital, science and technology (comprising education, universities, and the technological support system), markets, and business dynamics.
While the element (local-level) policy is not explicitly addressed in our model, it is intrinsically associated with features related to infrastructure, business dynamics, and human capital. The only dimension missing from our proposed model is entrepreneurial culture. However, as recent research underscores (Fritsch et al., 2019), such cultural traits are related to long-standing traditions and need adequate historical proxies, which are often unavailable for empirical exercises. Hence, our operational model offers a comprehensive perspective of EEs according to previous theoretical proposals, while remaining parsimonious as to address the entrepreneurial dynamics of ecosystems.

Because of the local nature of EEs, the literature has recognized cities as the most adequate loci for empirical assessments (Audretsch \& Belitski, 2017). Next, we address each of the five dimensions set out in the model in further detail.

\section{Science and technology}

Amongst the factors related to locational dynamics, access to a relevant knowledge base can be considered fundamental - more so for knowledge-intensive entrepreneurship (Nicotra et al., 2018; Boschma \& Martin, 2010). Rich technological environments tend to facilitate entrepreneurial activity at the local level (Nicotra et al., 2018). In the state of São Paulo, Brazil, city-level patenting activity is strongly related to the emergence of KIE activity (Fischer, Queiroz, \& Vonortas, 2018).

Universities and research institutes are strategic agents in this respect (Spigel, 2017; Stam, 2015). These institutions not only contribute to knowledge generation, they also shape local conditions related to the population's educational attainment (Isaksen \& Trippl, 2017; Dorfman, 1983). Therefore, geographical proximity to research-oriented universities and research centers can be a valuable source of knowledge for high-tech entrepreneurial activity (Stam, 2015).

Moreover, science-based entrepreneurship is significantly related to academic spin-offs (Di Gregorio \& Shane, 2003), a situation that attributes key relevance to the local presence of preeminent universities. Guerrero et al. (2016) proposed that universities and academic researchers are fundamental agents of innovation systems through their involvement with knowledge transfer and entrepreneurial activities. This helps explain why high-tech clusters are often attached to university campus towns (Isaksen \& Trippl, 2017). Fitjar and Rodríguez-Pose (2011) make such a case for regions that lack agglomeration economies while presenting high relative levels of innovative activity. However, universities' impact on strong entrepreneurial ecosystems is 
argued to be contingent upon the existence of a socioeconomic environment conducive to firm entry (Patton \& Kenney, 2010).

\section{Human capital}

Chatterji, Glaeser, and Kerr (2013) state that the key pillars of entrepreneurship are essentially related to human capital. This is associated with the general education of the workforce and the local supply of individuals with entrepreneurial inclinations. This feature is widely recognized in the literature, be it under the concepts of human capital (Isenberg, 2011; WEF, 2014), worker talent (Spigel, 2017), human resources (Nicotra et al., 2018), or talent pool (Stam, 2015). Notably, the ratio of high-tech employment often predicts entrepreneurial activity in regions (Motoyama \& Danley, 2012).

The availability of highly skilled labor is a structural precondition for the creation of innovative entrepreneurial systems (Bresnahan, Gambardella, \& Saxenian, 2001). Also, although labor is theoretically considered a mobile resource, entrepreneurial clusters are more likely to arise wherever professional talent is located or where it can be easily attracted (Dorfman, 1983). Accordingly, Audretsch and Feldman (1996) found that the propensity to cluster is stronger in industries that rely heavily on new economic knowledge, depending to a large degree upon skilled labor. This proximity allows KIE companies to more easily access available human capital (Storper, 1995).

In addition, opportunity-driven entrepreneurial activity is strongly related to local income levels (Radosevic \& Yoruk, 2013). Income approximates the level of education and capabilities within a pool of individuals and the quality of life and overall level of development of regions, key drivers of the location choices of knowledge-intensive entrepreneurs (Florida \& Mellander, 2014).

\section{Market dynamics}

The third dimension of interest in our EE model concerns market dynamics. Despite the likelihood that knowledge-intensive new ventures will be oriented towards global markets, locallevel conditions shape such ventures' access to necessary complementary resources (Florida \& Mellander, 2014). Larger markets offer increased levels of opportunities (Armington \& Ács, 2002) and demand diversity (Bosma, Schott, Terjesen, \& Penny, 2015). Isenberg (2010) follows this rationale, including local markets as significant vectors in the formation of entrepreneurial ecosystems. In addition, evidence from developed countries suggests that entrepreneurship tends to be more concentrated in large urban areas (Bosma \& Sternberg, 2014). Market size also feeds entrepreneurial endeavors from a different direction: the size of the population is a representation of the pool of potential entrepreneurs in a given location (Stuart \& Sorenson, 2003).

Our category of market dynamics also includes the available funding for knowledge-intensive entrepreneurs (Isenberg, 2010). Geographic proximity is a critical feature in this discussion, as larger distances between capitalists and entrepreneurs increase the monitoring costs involved in financing operations (Dorfman, 1983). This reflects the strategic relevance attributed to credit as a platform for start-ups to operate (Lerner, 2002; Feldman, 2001). Besides private flows of capital, governments can engage in financing these incipient ventures (Lerner, 2002). Considering the Brazilian context, this vector is particularly critical, as small and medium-sized companies find it excessively difficult to access funding mechanisms due to scarce credit lines (Neto, Farias Filho, \& Quelhas, 2014).

\section{Business dynamics}

Complementary to the idea of market dynamics, we introduce a perspective on the business environment of cities as an influential component of entrepreneurial ecosystems. Included here are the aspects of the level of development of regional economic structures, as well as its attractiveness for investments by incumbents.

The literature recognizes the importance of adjacent firms as a driver of local competitiveness (Stuart \& Sorenson, 2003). Positive externalities arise from the local clustering of firms, generating a critical mass of support for new companies (Isenberg, 2010; Isaksen \& Trippl, 2017; Storper, 1995). Incumbent firms can also leverage the growth conditions for new firms (WEF, 2014) providing incentives for new business creation and contributing to start-up survival (Delgado et al., 2010). Established firms, and particularly multinational corporations, also play an important role in setting the stage for the emergence of new, knowledgeintensive ventures (Brown \& Mason, 2017), as they can leverage overall capabilities in clusters (Bresnahan et al, 2001).

An additional item of interest concerns the geographical reach of large ("core") markets and how the proximity to these hubs can exert effects in neighboring areas. This happens because large cities do not just represent agglomeration of people, they are arguably also associated with the generation of innovative, sciencebased entrepreneurship (Duranton \& Puga, 2002). In this regard, an 
"efficiency gap" exists when comparing peripheral regions to those located close to large markets (Crescenzi \& Rodríguez-Pose, 2012). This is why high-tech clusters of entrepreneurship are frequently located in core regions (Isaksen \& Trippl, 2017). This situation can be magnified in regions such as the state of São Paulo, which includes a megahub that functions as a center for business services, venture capital, and corporate demand (WEF, 2018).

\section{Infrastructure}

The fifth dimension in our model deals with the quality of infrastructure, a platform upon which economic activity strongly relies. Infrastructure facilitates urban linkages, labor mobility, and knowledge flows (Audretsch et al., 2015). Thus, its impacts as a determinant of the formation of entrepreneurial ecosystems must be acknowledged (Spigel, 2017; Nicotra et al., 2018; Stuart \& Sorenson, 2003). The quality of physical infrastructure can also mitigate the detrimental effects associated with large market agglomeration diseconomies (Audretsch \& Belitski, 2017).

\section{Knowledge-intensive entrepreneurial ecosystems: Making the case for heterogeneous configurations}

Notwithstanding agreement on the very basic definitions of entrepreneurial ecosystems, there are persistent controversies on causal links within its intrinsic dynamics (Borissenko \& Boschma, 2016). What dimensions really matter for EEs? One of the main issues here concerns the poor generalizability of highly eminent cases to other contexts. These expositions - although informative - are developed around an idea of relative stability in the configuration of influential attributes in EEs. A first step in our approach deals with assessing the validity of such expectations. Hence, our first proposition can be stated as follows:

Proposition 1. Successful Entrepreneurial Ecosystems rely on a set of critical dimensions that shape their respective capacity of sustaining the generation of knowledge-intensive entrepreneurship.

On the other hand, researchers have increasingly criticized such formulations, as they lead to one-size-fits-all implications. Even if the dimensions included in these models are inclusive, some of its attributes may be more dominant in some cases than in others (Spigel, 2017). The central argument here is that economic mechanisms operate differently in distinct locations as a function of their historical backgrounds (Boschma \& Martin,
2010). This is why top-down policies that aim to organize clusters of entrepreneurship are often deemed ineffective (Bresnahan et al, 2001; Chatterji et al, 2013; Feldman, 2001).

This is the pillar of Evolutionary Economic Geography (EEG). In dealing with the dynamics of entrepreneurial ecosystems, the evolutionary view pinpoints the relevance of pre-existing conditions and assets for ecosystems to emerge (Isaksen, 2016). Accordingly, new science-based firms can be understood as functions of the prior existence of scientific research undertaken by universities and research institutes in a given location (Feldman \& Lendel, 2011). In this debate, we hope to add the perspective that, because of distinct evolutionary paths, entrepreneurial ecosystems can achieve efficiency through different configurations. In other words, the relevance of EEs' dimensions is bounded by location-specific trajectories, thus altering the dynamics of interconnection among actors, institutions, and organizations. Accordingly, our second proposition is presented:

Proposition 2. Because of idiosyncratic evolutionary paths, Entrepreneurial Ecosystems can present heterogeneous configurations in terms of relevant drivers without compromising their respective level of entrepreneurial propensity.

Recent literature has indicated some efforts in a similar direction. Brown and Mason (2017) develop a simplified taxonomy of entrepreneurial ecosystems based on illustrative cases of "embryonic" and "scale-up" locations. By assessing this argument, our goal is to empirically refine these introductory propositions and provide a more nuanced view on the variegated combinations of characteristics that can form a functional EE.

\section{METHODOLOGICAL APPROACH}

To address our research questions, we use Fuzzy-Set Qualitative Comparative Analysis (QCA). QCA is a method that is used to identify configurations or "recipes" of causal conditions associated with different outcomes, following the "equifinality principle," meaning that multiple paths or solutions can lead to the same outcome (Ragin, 2008). Different from regression analysis, QCA also follows the principle of causal complexity, accounting for the combination of causal measures to a specific outcome within a property space. Analytical benefits associated with the QCA approach in comparison with standard econometric techniques applied to address the dynamics of entrepreneurial ecosystems concern its capacity for developing robust evaluations 
of configurational issues (Fiss et al., 2013). While this is an aspect of interest in this field, traditional regression models fall short in offering the necessary knowledge for such research questions. Moreover, there is an increasing interest in the use of QCA in entrepreneurship studies (Kraus et al., 2018).

The basic locus of empirical information in this study is knowledge-intensive entrepreneurship in the state of São Paulo, Brazil. The grants of the PIPE program are used as a proxy for KIE activity. This program is funded by the Fundação de Amparo à Pesquisa do Estado de São Paulo (Research Foundation of the state of São Paulo [FAPESP]) to support innovative initiatives in small enterprises. The program has a similar structure and objectives to the Small Business Innovation Research (SBIR) program in the United States. While SBIR data has been used in the context of entrepreneurial ecosystems by an extensive body of research (e.g. Wallsten, 2001; Qian \& Haynes, 2014), information from PIPE has only recently been used for these purposes (e.g. Fischer et al., 2018). Such sources provide robust evidence on KIE activity, but also introduce sample bias in the analysis, since they deal with pre-selected and funded R\&D projects that are often attached to academic spin-offs. Hence, conclusions drawn from this group should be taken cautiously, as they do not necessarily represent the broader context of overall KIE firms.

The full dataset includes 1130 grants allocated across 114 cities in the state during the period 1998-2014. We collected data for a total of 299 cities in the state of São Paulo in order to account for differences in configurations between cities that have received project grants and those that have not. City-level analysis was chosen due to the local nature of entrepreneurial ecosystems, in which cities seem to be the most appropriate units of analysis (Audretsch \& Belitski, 2017). While QCA has typically been used as a research methodology for Small- $N$, comparative work in the case-oriented tradition (Ragin, 1987), the method has increasingly been applied to examine large- $\mathrm{N}$ phenomena (Fiss, et al., 2013; Greckhamer et al., 2013; Emmenegger et al., 2014). Small-N samples in QCA range from 12-50 cases, whereas, Large- $\mathrm{N}$ samples involve 50+ cases (Greckhamer et al., 2013).

\section{Model and unit of analysis}

Following the literature review and the graphical representation of our analytical model (Figure 1), the socioeconomic dimensions included in our assessment are described in Exhibit 1. Most variables represent averages of city-level characteristics as proxies for economic conditions. This procedure avoids problems related to year-to-year variations, while also controlling for the time span during which projects have started (1998-2014).

\section{Calibration procedures}

Qualitative Comparative Analysis works using the principle of set-theoretic “membership." We used quartiles to calibrate the fuzzy-sets. The only exception to this rule was the causal condition RESUNI, which is a binary variable indicating the presence (absence) of a major research university in the city. For the variable PROXCAP, quartiles were obtained by using only the cities that have displayed the outcome. This was done with the intent of creating a better visual geographical distribution and separation of cases. For the outcome variable, a rather flexible threshold was used to generate enough diversity in the sample and avoid skewness. We used the following set-membership threshold for our outcome variable: above 10 projects (full membership), between 4 to 10 projects (more-in-than-out), between 2 to 4 (moreout-than-in), and below 2 (full non-membership).

\section{Necessary conditions}

Conditions are considered necessary when they represent the superset of the outcome, that is, when the set membership values for the outcome $Y$ are lower than that for a given causal condition (Ragin, 2006). Necessary conditions are verified using the following formulas for Consistency and Coverage.

\begin{tabular}{|c|c|}
\hline Consistency: $\sum\left\{\min \left(X_{i}, Y_{i}\right)\right] / \sum\left(Y_{i}\right)$ & (1) \\
\hline Covergage: $\left(Y_{i} \leq X_{i}\right): \sum\left\{\min \left(X_{i}, Y_{i}\right)\right] / \sum\left(X_{i}\right)$ & (2) \\
\hline
\end{tabular}

According to Ragin (2008, p. 44), “consistency addresses the degree to which instances of the outcome agree in displaying the causal condition to be necessary, while coverage assesses the degree to which instances of the condition are paired with instances of the outcome." Coverage indicates the relevance or importance of a set-theoretic connection. However, necessary conditions may be considered trivial if a condition is present in most cases whether the outcome is present or not (Schneider \& Wagemann, 2012).

\section{Sufficient conditions}

The second test intends to identify the combinations of conditions that are in accordance with the presence of KIE activity, thus forming knowledge-intensive entrepreneurial ecosystems. A sufficient condition is one that, if satisfied, results in the achievement of the outcome (Schneider \& Wagemann, 2012, 
p.57). Fuzzy-sets are converted into crisp-sets with a value of 1 or 0 if the set membership score on fuzzy-sets falls above or below 0.5 . This generates a truth table with the property space of different combinations or configurations of conditions that lead to the outcome. We analyzed the truth table correlating the membership scores of different conditions with the intensity of entrepreneurial activity to identify different configurations associated with entrepreneurial ecosystems. After setting the cutoff point in the truth table (above 0.75), we generate three types of solutions: complex (CS), parsimonious (PS), and intermediate (IS).
For robustness in our analysis of cause-consequence relations, the parsimonious (PS) and intermediate solutions (IS) are recommended, as they simplify the statements and assumptions on the main causal conditions for a given set of variables. We used these solutions to derive our "core" and "contributing" causal conditions. For the configurational analysis, we used the complex solution (CS). The CS provides a general description of different sufficient causal paths that can be observed in cases in which the outcome is present with a consistency level above 0.75 .

\section{Exhibit 1. Variable description and sources}

\begin{tabular}{|c|c|c|c|}
\hline Dimension & Variables Outcome & Definition & Source \\
\hline \multirow{2}{*}{$\begin{array}{l}\text { Science and } \\
\text { technology }\end{array}$} & KIE PROJECTS & Number of projects granted to a given municipality. & PIPE/FAPESP \\
\hline & $\begin{array}{l}\text { Research Universities } \\
\text { (RESUNI) }\end{array}$ & $\begin{array}{l}\text { Existence of at least one major research-oriented university or } \\
\text { university campus with focus on STEM in the city. Dummy variable. }\end{array}$ & $\begin{array}{l}\text { Ministry of Education and } \\
\text { Culture (Brazil) }\end{array}$ \\
\hline \multirow[t]{2}{*}{$\begin{array}{l}\text { Human } \\
\text { capital }\end{array}$} & $\begin{array}{l}\text { Human Development } \\
\text { (HDI-M) }\end{array}$ & Average municipal Human Development Index 1991, 2000, 2010. & $\begin{array}{l}\text { São Paulo State Statistics } \\
\text { Office (SEADE) }\end{array}$ \\
\hline & $\begin{array}{l}\text { Knowledge-Intensive } \\
\text { Jobs } \\
\text { (KIJOBS) }\end{array}$ & $\begin{array}{l}\text { Average weight of selected knowledge-intensive jobs (STEM } \\
\text { activities) in cities' total labor force, 2001-2014. }\end{array}$ & $\begin{array}{l}\text { Employment, General } \\
\text { Register of Employed and } \\
\text { Unemployed Persons } \\
\text { (CAGED) }\end{array}$ \\
\hline \multirow[t]{2}{*}{$\begin{array}{l}\text { Market } \\
\text { dynamics }\end{array}$} & $\begin{array}{l}\text { Gross Domestic } \\
\text { Product (GDP) }\end{array}$ & Average GDP 1999-2012 (constant 2012 Reais). & $\begin{array}{l}\text { São Paulo State Statistics } \\
\text { Office (SEADE) }\end{array}$ \\
\hline & $\begin{array}{l}\text { Credit } \\
(\text { CRED })\end{array}$ & Average credit operations per capita 1993-2013 (constant 2014 Reais) & $\begin{array}{l}\text { São Paulo State Statistics } \\
\text { Office (SEADE) }\end{array}$ \\
\hline \multirow[b]{2}{*}{$\begin{array}{l}\text { Business } \\
\text { dynamics }\end{array}$} & $\begin{array}{l}\text { Business } \\
\text { Concentration } \\
\text { (BusCONC) }\end{array}$ & $\begin{array}{l}\text { Average weight (\%) of total city-level businesses in the state's total, } \\
2008-2011 .\end{array}$ & $\begin{array}{l}\text { The Brazilian Institute of } \\
\text { Geography and Statistics } \\
\text { (IBGE) }\end{array}$ \\
\hline & $\begin{array}{l}\text { Multinational } \\
\text { Investment } \\
(\text { MNE-I) }\end{array}$ & $\begin{array}{l}\text { Announced investments from multinational enterprises in selected } \\
\text { Knowledge-Intensive Activities at the city/- level in the state of } \\
\text { São Paulo. Includes expansion and greenfield investments. Data } \\
\text { represents the average investment for the } 2002-2014 \text { period in } \\
\text { millions of USD. }\end{array}$ & $\begin{array}{l}\text { São Paulo State Statistics } \\
\text { Office (SEADE) }\end{array}$ \\
\hline Infrastructure & $\begin{array}{l}\text { Urbanization } \\
\text { (URB) }\end{array}$ & Average percentage of urban territory, 1992-2014. & $\begin{array}{l}\text { São Paulo State Statistics } \\
\text { Office (SEADE) }\end{array}$ \\
\hline
\end{tabular}




\section{RESULTS}

We proceeded sequentially, starting the empirical analysis by verifying whether there is any condition that could be considered necessary for KIE ecosystems to arise, then moving to the analysis of sufficiency and the different configurations (or "recipes") of dynamics in these ecosystems.

\section{Necessary conditions}

As a first step in our analysis, we tested if any of the twelve conditions as well as the negation $(\sim)$ of these conditions could represent necessary conditions for the outcome (Table 1). Patents per capita (PATENTS), income (GDP), skilled personnel (HDI-M), business intensity (BUSCONC), POP, degree of urbanization (URB), and STEM job intensity (KIJOBS) reached a consistency level above the necessary threshold of 0.9. However, all these conditions exhibited very low coverage, meaning that they are likely trivially necessary. On the other hand, the absence or negation $(\sim)$ of RESUNI and MNE-I are necessary conditions for the absence of
KIE projects. Both reached a consistency level above a 0.9 with high coverage.

\section{Sufficient conditions}

Sufficiency analysis takes us closer to the identification of the drivers of KIE ecosystems. Table 2 presents the truth table with the top combinations. Due to the extension of the analysis, we only present results for the top 17 combinations of causal conditions (A-P) here. We set our cut-off consistency score at 0.76 following the general consistency benchmark proposed by Ragin (2008). Empirically, this cut-off point also allows us to capture the totality of the most relevant innovation ecosystems in the state of São Paulo. These represent seven combinations of conditions ( $A$ to $F$ ) that were considered most relevant for the analysis. While these seven combinations incorporate just 16 cities $5.35 \%$ of the whole sample or $14.04 \%$ of the cities that have received knowledge-intensive projects grants), they account for 894 projects $(79.12 \%$ of the total number of KIE projects). We then derive two types of solutions: parsimonious (PS) and intermediate solutions (IS) (Table 3).

\section{Table 1. Analysis of necessary conditions}

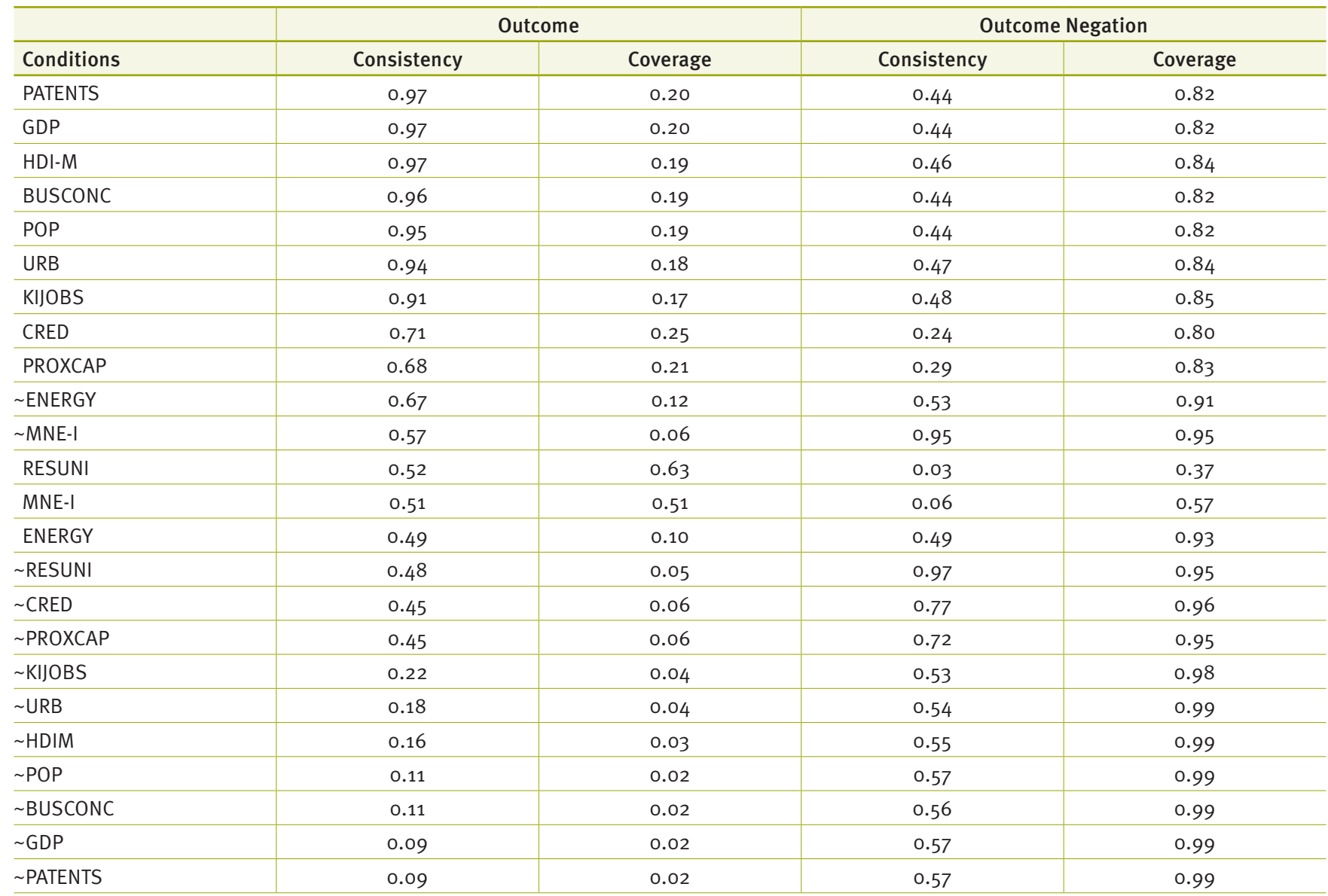


Table 2. Truth table and cities (cases with consistency below 0.26 and logical reminders not listed)

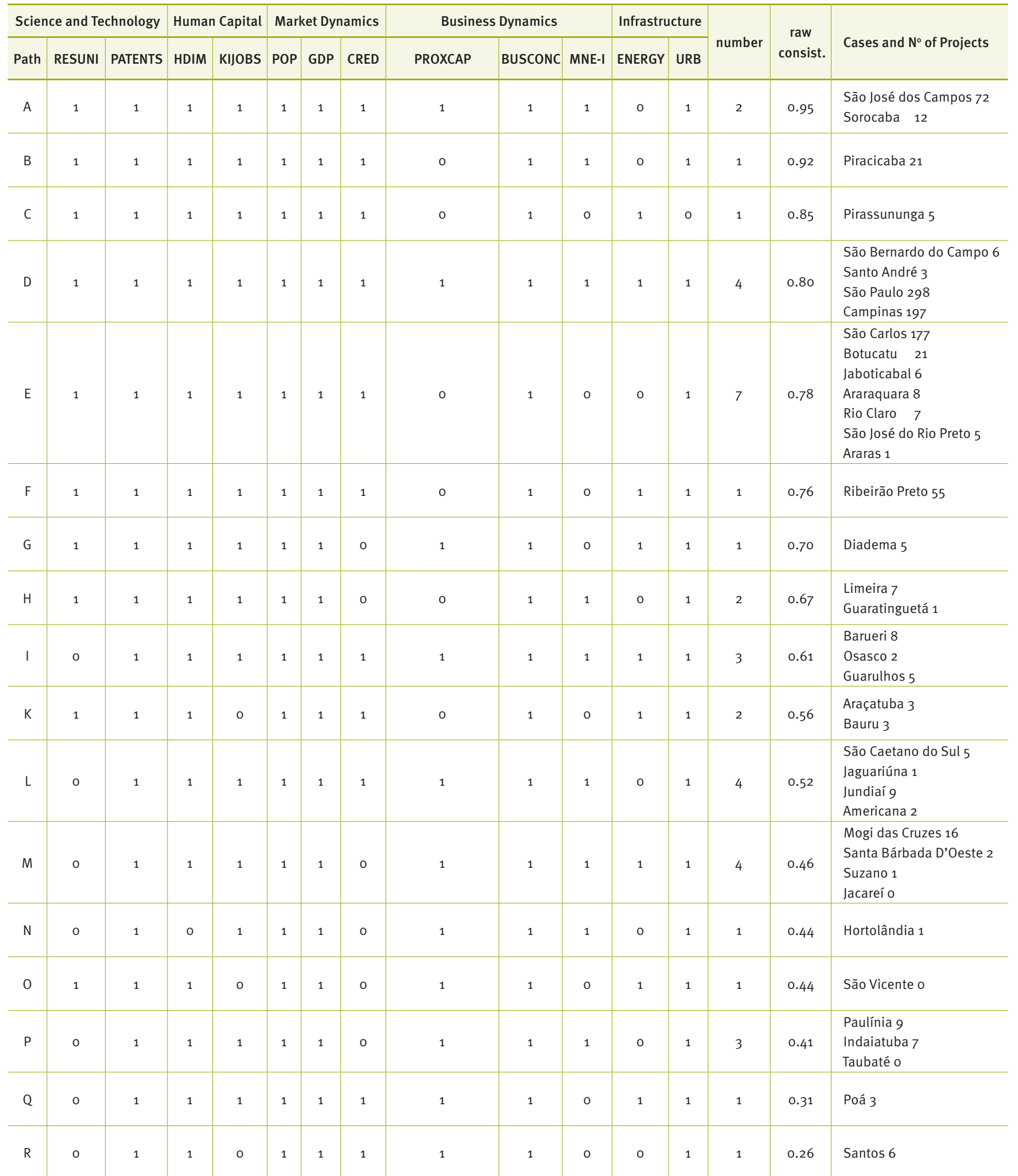

*Number is the frequency of observations; Raw consist: consistency levels. Case presents the cities in analysis. The number within parentheses corresponds to the number of KIE projects granted to the city. 


\section{Table 3. Sufficient combination of conditions for high KIE activity}

Parsimonious Solutions

\begin{tabular}{|c|c|c|c|c|}
\hline Path & Recipe & $\begin{array}{c}\text { raw } \\
\text { coverage }\end{array}$ & $\begin{array}{c}\text { unique } \\
\text { coverage }\end{array}$ & consistency \\
\hline \multirow[t]{3}{*}{1} & RESUNI*KIJOBS*CRED & 0.39 & 0.39 & 0.84 \\
\hline & Solution coverage & 0.39 & & \\
\hline & Solution consistency & 0.84 & & \\
\hline
\end{tabular}

Intermediate Solutions

\begin{tabular}{|c|c|c|c|c|}
\hline Path & Recipe & $\begin{array}{c}\text { raw } \\
\text { coverage }\end{array}$ & $\begin{array}{c}\text { unique } \\
\text { coverage }\end{array}$ & consistency \\
\hline 1 & RESUNI*PATENTS*HDIM*KIJOBS*POP*GDP*CRED*BUSCONC*URB & 0.38 & 0.202 & 0.84 \\
\hline \multirow[t]{3}{*}{2} & RESUNI*PATENTS*HDIM*KIJOBS*POP*GDP*CRED*BUSCONC*ENERGY & 0.19 & 0.006 & 0.79 \\
\hline & Solution coverage & 0.39 & & \\
\hline & Solution consistency & 0.84 & & \\
\hline
\end{tabular}

The parsimonious solution considers counterfactuals in order to simplify the assumptions that lead to the outcome. In this approach, research universities, knowledge-intensive jobs, and credit can be seen as core ingredients that lead to the outcome. The IS takes into account counterfactuals in order to simplify the assumptions relative to the conditions that lead to our outcome. The intermediate solution generates two paths; both of which have RESUNI, PATENTS, HDIM, KIJOBS, POP, GDP, CRED, and BUSCONC. Cities with these features are more likely to present knowledge-intensive entrepreneurial activity. This is consistent with $84 \%$ of the cases in the intermediate solution. An important aspect to note in the intermediate solution (IS) is the suppression of MNE-I and PROXCAP as causal conditions. These variables can be considered superfluous conditions in this first step of the analysis.

\section{Configurations of Knowledge-Intensive Entrepreneurial Ecosystems}

In order to dig deeper into the configurational patterns of the most relevant entrepreneurial ecosystems in the state of São Paulo, we use the complex solution (CS). Exhibit 2 shows the causal paths for the complex solution obtained in our analysis, consisting of three paths. The overall consistency of the solution is 0.85 . The CS solutions help identify the different configurations of the most relevant entrepreneurial ecosystems in our sample. RESUNI, PATENTS, HDIM, POP, GDP, CRED, and BUSCONC are present in all three paths. These conditions seem to be a shared base for the main KIE Ecosystems. Differences arise on the basis of KIJOBS, PROXCAP, MNE, ENERGY, and URB. These results signal the existence of variegated structures in entrepreneurial ecosystems, even though they fundamentally rely on a common core involving the science and technology environment, market and business dynamics, and human capital.

The first path is of high importance given its raw and unique coverage. Besides the common core of EE conditions, this group includes cities that are close to the main economic hub and with significant amounts of MNE investment. It is also characterized by high levels of urban population. Path 3 stands for a clear representation of a "core" entrepreneurial ecosystem. The second path of the complex solution adds KIJOBS, PROXCA $P$, URB, and $\sim$ ENERGY to the common conditions. This profile of entrepreneurial ecosystems is characterized by a high presence of knowledge-intensive jobs, distance from the main economic hub (city of São Paulo), high levels of urban population, and relatively low per capita consumption of energy. Path 2 seemingly stands for a typical configuration of peripheral entrepreneurial ecosystems. 


\section{Exhibit 2. Configurational Paths of Knowledge Intensive Innovation Ecosystems}

Complex Solution

\begin{tabular}{|c|c|c|c|c|}
\hline Path & Recipe & $\begin{array}{c}\text { raw } \\
\text { coverage }\end{array}$ & $\begin{array}{c}\text { unique } \\
\text { coverage }\end{array}$ & consistency \\
\hline 1 & RESUNI*PATENTS*HDIM*KIJOBS*POP*GDP*CRED* PROXCAP*BUSCONC*MNE-I* URB & 0.20 & 0.14 & 0.87 \\
\hline 2 & RESUNI*PATENTS*HDIM*KIJOBS*POP*GDP*CRED* $\sim \mathrm{PROXCAP}^{\star} \mathrm{BUSCONC}^{*} \sim \mathrm{ENERGY}^{\star} \mathrm{URB}$ & 0.20 & 0.10 & 0.82 \\
\hline \multirow[t]{3}{*}{3} & RESUNI*PATENTS*HDIM*KIJOBS*POP*GDP*CRED* $\sim$ PROXCAP*BUSCONC* $\sim$ MNE-I*ENERGY & 0.08 & 0.03 & 0.77 \\
\hline & Solution coverage & 0.37 & & \\
\hline & Solution consistency & 0.85 & & \\
\hline
\end{tabular}

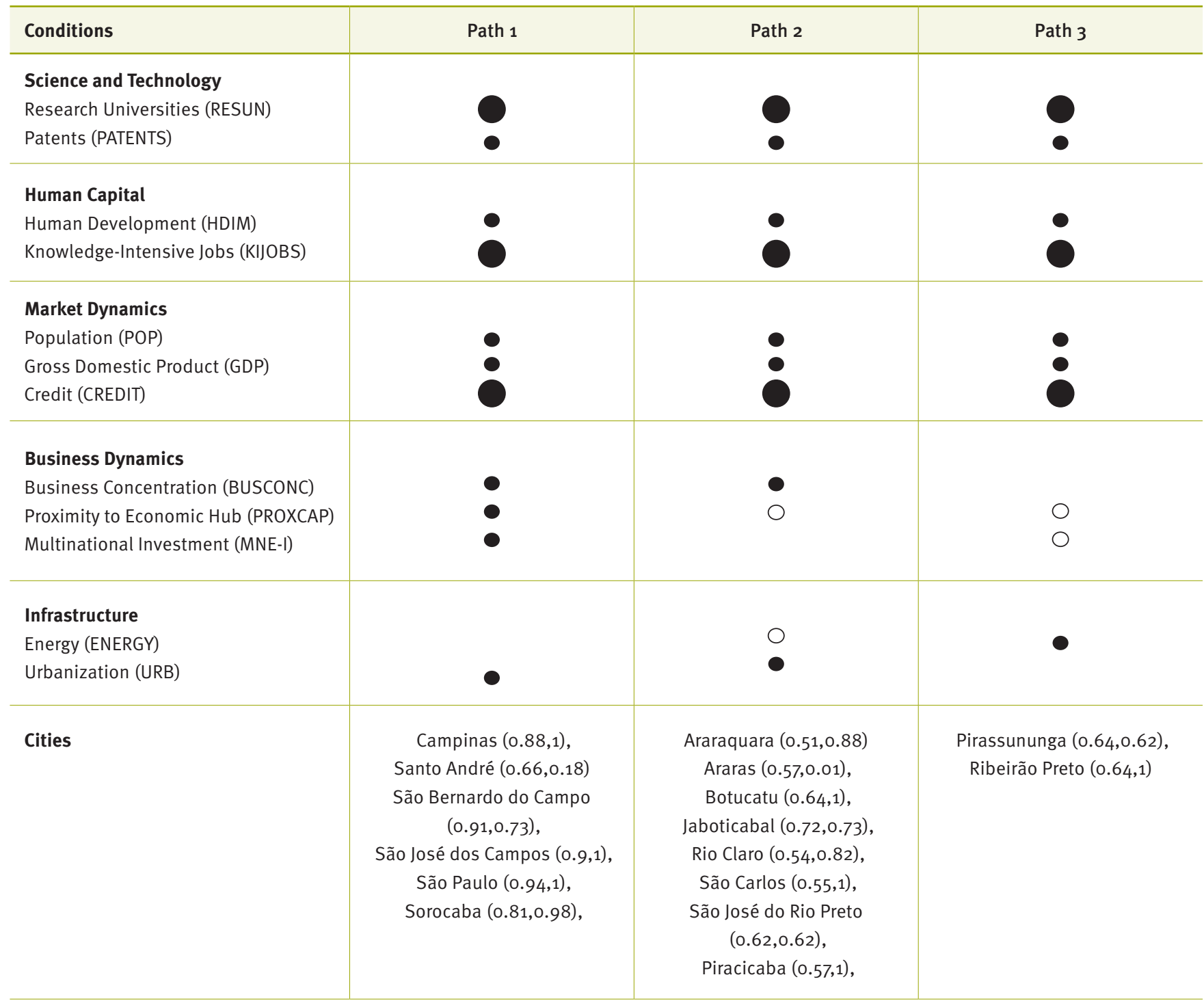


The third path of the complex solution is slightly different from the second with the positive presence of ENERGY (as a proxy for infrastructural conditions), but with the suppression of URB. Also, it presents the explicit relevance for the absence of MNE-I. Similar to the second path, cities covered by the third solution are far from the main economic hub. However, this group includes a regional economic center, the city of Ribeirão Preto. In any case, this seems to represent an alternative configuration of entrepreneurial ecosystems located outside the geographic reach of the city of São Paulo, consisting of an additional profile of peripheral EE.

Figure 2 presents the spatial distribution of these configurations. The blue marks show the cities that were selected by constructing the truth table (Table 2) above the 0.76 consistency threshold. The green marks present relatively significant innovation ecosystems that fell below the consistency threshold of 0.76 in Table 2. Interestingly, these cities are geographically located inside a technological corridor of EEs.

\section{Figure 2. Mapping KI-entrepreneurial ecosystems in the state of SP}

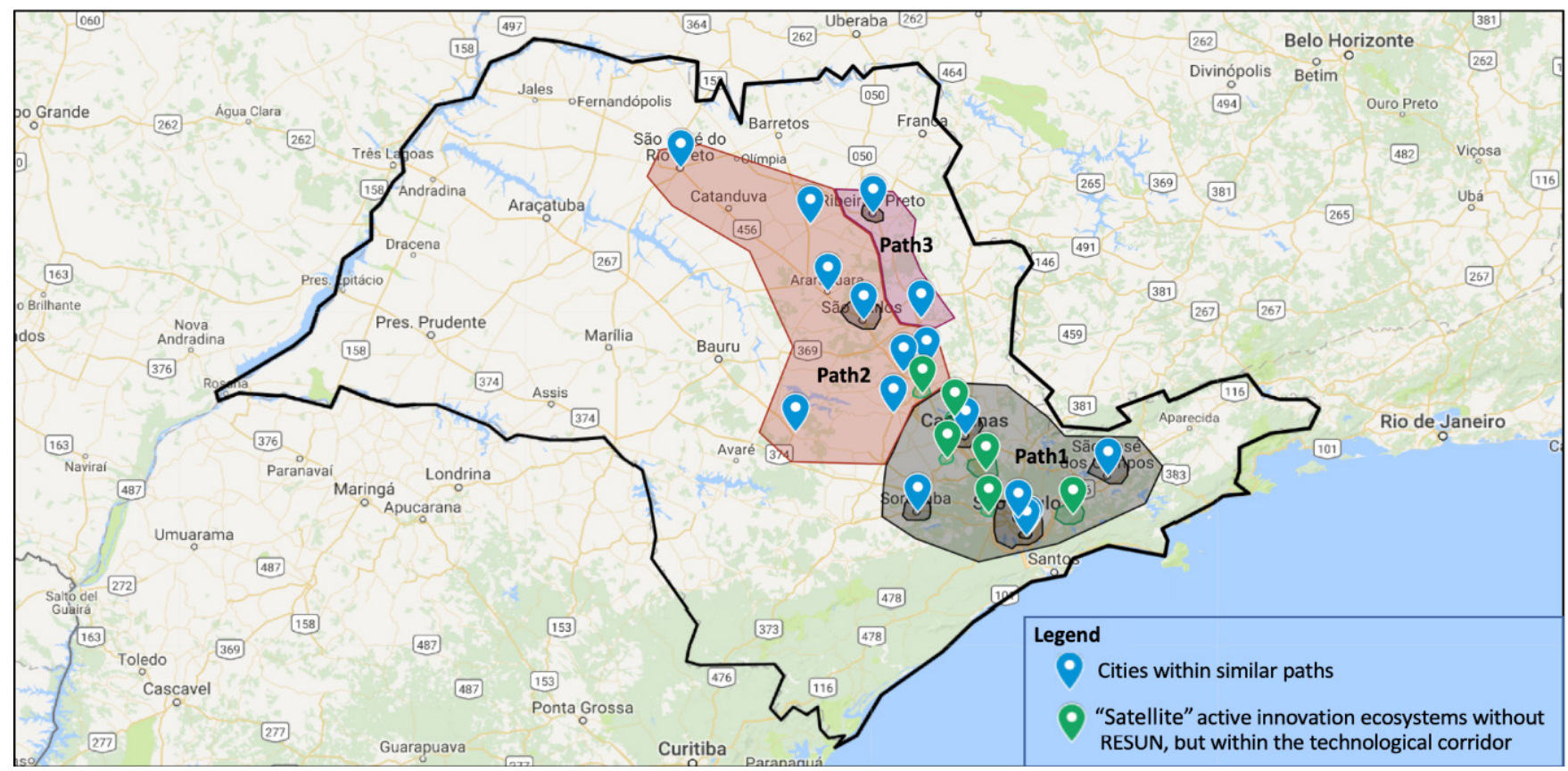

Source: Authors (based on research data)

\section{DISCUSSION AND CONCLUDING}

\section{REMARIS}

Our assessment highlights the existence of heterogeneous configurations in entrepreneurial ecosystems in the state of São Paulo, Brazil, supporting our second proposition. A common core of features arises, nonetheless, in accordance with Proposition 1 and suggesting a coexistence of the dynamics contained in both assumptions. This provides novel empirical findings that support the expectations set by arguments contained in evolutionary economic geography arguments, offering a multiscalar perspective of distinct ecosystems and their differential dynamics (Alvedalen \& Boschma, 2017; Borissenko \& Boschma,
2016; Boschma \& Martin, 2010) as well as the multidimensional perspective of agents embedded in these processes (Carayannis et al., 2017). It also highlights a hierarchy of attributes (Spigel, 2017) and reserves a key role for the knowledge context as a precondition for EEs to prosper (Feldman \& Lendel, 2011).

The first dimension of interest concerns science and technology. The existence of preeminent research universities and strong technological activity are key drivers of knowledgeintensive entrepreneurship, as they leverage local stocks of knowledge capital. Local market dynamics (represented by economic size - GDP and population - and credit availability) have a strong impact on cities' propensities to generate KIE activity. The validity of these two dimensions indicate a 
balance between technological and market forces in the nature of entrepreneurial ecosystems, pinpointing their multifaceted character (Isenberg, 2010; Mason \& Brown, 2014). Also, the inclusion of business concentration in this "common core" highlights the importance of localization economies and complementary productive structures (Isaksen \& Trippl, 2017; Delgado et al., 2010).

Complementing this perspective, we can identify the influence of human capital as a pillar of EEs. Together, these assertions suggest clear implications for policymakers. Beyond the relevance of a strong educational infrastructure, a somewhat counterintuitive platform could be fruitful: attracting incumbent firms that are engaged in intensive technological development and in the use of knowledge-intensive labor. While this alternative is seldom linked to the notion of entrepreneurship promotion, it can shape the contextual conditions in which KIE may arise.

The infrastructure dimension appeared to provide shaky contributions - in some cases it was found positively related to KIE activity, while in others it seems to exert negative impacts. This may be due to the operational variables applied, as they stand for city-level averages and we should not rule out the existence of "pockets" of infrastructural excellence within these analytical units. This might be the case considering extreme heterogeneity in infrastructural quality inside urban areas a market feature of the economic geography in developing countries (Glaeser, 2014). Another interesting result concerns the heterogeneity of influence attributed to distance from the main economic hub in the state. Our results indicate that both core and peripheral regions are capable of establishing prosperous levels of entrepreneurial activity, contrary to propositions stating a loss of innovative capability in areas located outside the reach of economic centers (Crescenzi \& Rodríguez-Pose, 2012).

The main message from our empirical findings is that entrepreneurial ecosystems are diverse in their configurations, and that comprehensive models may fail to address locational idiosyncrasies. In turn, this conceptual misfit is likely to lead to inadequate interventions. By ignoring the local context, these top-down initiatives from policymakers to steer the development of clusters are usually unsuccessful (Martin \& Sunley, 2003). Instead, resources should be directed toward enabling policymakers to understand local idiosyncrasies in terms of innovation and entrepreneurial dynamics (Isaksen \& Trippl, 2017). Accordingly, the government's role in fostering entrepreneurial ecosystems must be one of facilitating (not leading or controlling) preexisting local strengths and capabilities (Isenberg, 2010). A straightforward implication for policymakers in this regard is the need to conduct thorough diagnostics of local-level characteristics prior to implementing entrepreneurship-oriented initiatives. Such efforts are likely to indicate courses of action that fit regional profiles (Jucevicius et al., 2016).

While these are fundamental preconditions for adequate policies to emerge, our results also pinpoint the existence of necessary circumstances for KIE to thrive. This may be unfortunate news for several locations, as many of the influential drivers take a long time to mature and they are outside the reach of policymaking processes. This is the case for most of the indicators that are part of the EE common core in our analysis. Perhaps more challenging than that is the fact that several of these indicators can be taken as endogenous with respect to knowledge-intensive entrepreneurship (Alvedalen \& Boschma, 2017; Stam, 2015). Hence, particularly in the short term, "engineering" entrepreneurial ecosystems through public policy may be highly ineffective. This carries practical and theoretical implications for both researchers and policymakers, since it indicates that the "organic" nature of EEs is likely to downplay impacts of centralized initiatives aiming at fostering KIE (Carayannis et al., 2017; Jucevicius, 2016). On the other hand, they ways in which these aspects interact in the long run is an issue that still deserves further research.

Such findings also bear significance for knowledgeintensive entrepreneurs. These individuals and firms are not merely passive agents within the dynamics of entrepreneurial ecosystems. Instead, establishing connections and fostering the formation of networks and a supportive business structure are events in which entrepreneurs play an active role (Feldman, 2001). While location strategies can be derived from specific features - such as those pointed out by our research - benefits from ecosystems can arise mainly from open innovation approaches to management (Erina et al., 2017).

We expect our research to contribute to the debate around the evolutionary character of entrepreneurial ecosystems. Further testing of the propositions contained in this article, along with the use of different variables and dimensions, could provide more in-depth insights into this inquiry. In addition, analyzing evidence from countries and regions in different stages of development is desirable, as some traits identified in our sample may not hold in other contexts. Such appraisals are needed in order to overcome the limitations of our methodological approach, mostly concerning the sample of knowledge-intensive entrepreneurs and the parameters used to identify successful cases of entrepreneurial 
ecosystems. This discussion based on empirical evidence is paramount for advancing the quality of entrepreneurial policymaking and maximizing the benefits that may emerge from these new ventures.

\section{RAE'S NOTE}

A preliminary version of this article was presented at the $X$ Encontro de Estudos em Empreendedorismo e Gestão de Pequenas Empresas (EGEPE), promoted by the Associação Nacional de Estudos em Empreendedorismo e Gestão de Pequenas Empresas (ANEGEPE) in partnership with Centro de Empreendedorismo e Novos Negócios (FGVceen) and the Faculdade de Ciências Aplicadas da Unicamp (FCA) and its Laboratório de Empreendedorismo, Inovação e Comércio Internacional (LEICI).

\section{ACKNOWLEDGEMENTS}

We wish to thank the Fundação de Amparo à Pesquisa do Estado de São Paulo (São Paulo Research Foundation [FAPESP]) by funding (Fapesp Grant \# 2016/17801-4 and 2013/50524-6).

\section{REFERENCES}

Ács, Z., \& Armington, C. (2004). Employment growth and entrepreneurial activity in cities. Regional Studies, 38(8), 911-927. doi:10.1080/0034340042000280938

Ács, Z., Autio, E., \& Szerb, L. (2014). National systems of entrepreneurship: Measurement issues and policy implications. Research Policy, 43(3), 476-494. doi:10.1016/j.respol.2013.08.016

Ács, Z., Stam, E., Audretsch, D., \& O'Connor, A. (2017). The lineages of the entrepreneurial ecosystem approach. Small Business Economics, 49(1), 1-10. doi:10.1007/s11187-017-9864-8

Alvedalen, J., \& Boschma, R. (2017). A critical review of entrepreneurial ecosystems research: Towards a future research agenda. European Planning Studies, 25(6), 887-903. doi:10.1080/09654313.2017.1299 694

Armington, C., \& Ács, Z. J. (2002). The determinants of regional variation in new firm formation. Regional Studies, 36(1), 33-45. doi:10.1080/00343400120099843

Audretsch, D. (2012). Entrepreneurship research. Management Decision, 50(5), 755-764. doi:10.1108/00251741211227384
Audretsch, D., \& Belitski, M. (2017). Entrepreneurial ecosystems in cities: Establishing the framework conditions. Journal of Technology Transfer, 42(5), 1030-1051. doi:10.1007/s10961-016-9473-8

Audretsch, D., \& Feldman, M. (1996). R\&D spillovers and the geography of innovation and production. The American Economic Review, 86(3), 630-640.

Audretsch, D. B., Heger, D., \& Veith, T. (2015). Infrastructure and entrepreneurship. Small Business Economics, 44(2), 219-230. doi:10.1007/s11187-014-9600-6

Borissenko, Y., \& Boschma, R. (2016). A critical review of entrepreneurial ecosystems: Towards a future research agenda. [Papers in Evolutionary Economic Geography \#16.30]. Utrecht University - Urban \& Regional Research Centre.

Boschma, R., \& Martin, R. (2010). The aims and scope of evolutionary economic geography. [Papers in Evolutionary Economic Geography \#10.01]. Utrecht University - Urban \& Regional Research Centre.

Bosma, N. S., Schott, T., Terjesen, S., \& Penny, K. (2015). Global entrepreneurship monitor. Babson College, London Business School and Global Entrepreneurship Research Association (GERA).

Bosma, N., \& Sternberg, R. (2014). Entrepreneurship is an urban event? Empirical evidence from European cities. Regional Studies, 48(6), 1016-1033. doi:10.1080/00343404.2014.904041

Bresnahan, T., Gambardella, A., \& Saxenian, A. (2001). Old economy inputs for new economy outcomes: cluster formation in the new Silicon Valleys. Industrial and Corporate Change, 10(4), 835-860.

Brown, R., \& Mason, C. (2017). Looking inside the spiky bits: A critical review and conceptualization of entrepreneurial ecosystems. Small Business Economics, 49(1), 11-30. doi:10.1007/s11187-017-9865-7

Carayannis, E., Grigoroudis, E., Campbell, D., Meissner, D., \& Stamati, D. (2017). The ecosystem as helix: An exploratory theory-building study of regional co-opetitive entrepreneurial ecosystems as Quadruple/ Quintuple Helix Innovation Models. R\&D Management, 48(1), 148 162. doi:10.1111/radm.12300

Chatterji, A., Glaeser, E., \& Kerr, W. (2013). Clusters of entrepreneurship and innovation. [Working Paper 19013]. National Bureau of Economic Research Working Paper Series.

Crescenzi, R., \& Rodríguez-Pose, A. (2012). An integrated framework for the comparative analysis of the territorial innovation dynamics of developed and emerging countries. Journal of Economic Surveys, 26(3), 517-533. doi:10.1111/j.1467-6419.2012.00726.x

Delgado, M., Porter, M., \& Stern, S. (2010). Clusters and entrepreneurship. Journal of Economic Geography, 10(4), 495-518. doi:10.1093/jeg/ lbq010

Di Gregorio, D., \& Shane, S. (2003). Why do some universities generate more start-ups than others? Research Policy, 32(2), 209-227. doi:10.1016/Soo48-7333(02)00097-5

Dorfman, N. (1983). Route 128: the development of a regional high technology economy. Research Policy, 12(6), 299-316. doi:10.1016/0048-7333(83)90009-4 
Duranton, G., \& Puga, D. (2002). Diversity and Specialisation in Cities: Why, Where and When Does It Matter? in P. McCann (Ed.). Industrial Location Economics (pp. 151-186). Cheltenham, UK: Edward Elgar.

Emmenegger, P., Schraff, D., \& Walter, A. (2014). QCA, the truth table analysis and large-N survey data: The benefits of calibration and the importance of robustness tests. In: 2nd International QCA Expert Workshop, November, Zurich, Switzerland.

Erina, I., Shatrevich, V., \& Gaile-Sarkane, E. (2017). Impact of stakeholder groups on development of a regional entrepreneurial ecosystem. European Planning Studies, 25(5), 755-771. doi:10.1080/09654313. 2017.1282077

Feldman, M. (2001). The entrepreneurial event revisited: Firm formation in a regional context. Industrial and Corporate Change, 10(4), 861. 891. doi:10.1093/icc/10.4.861

Feldman, M., \& Lendel, I. (2011). The Emerging Industry Puzzle. Optics Unplugged', in H. Bathelt, M. P. Feldman, and D. F. Kogler (Eds.). Beyond Territory. Dynamic Geographies of Knowledge Creation, Diffusion, and Innovation (pp. 107-148). London and New York: Routledge.

Fischer, B., Queiroz, S., \& Vonortas, N. (2018). On the location of knowledgeintensive entrepreneurship in developing countries: Lessons from São Paulo, Brazil. Entrepreneurship and Regional development, 30(5-6), 612-638. doi:10.1080/08985626.2018.1438523

Fiss, P., Sharapov, D., \& Cronqvist, L. (2013). Opposites attract? Opportunities and challenges for integrating Large-N QCA and econometric analysis. Political Research Quarterly, 66(1), 191-198. doi:10.1177/1065912912468269e

Fitjar, R., \& Rodríguez-Pose, A. (2011). Innovating in the periphery: Firms, values and innovation in Southwest Norway. European Planning Studies, 19(4), 555-574. doi:10.1080/09654313.2011.548467

Florida, R. (2005). The world is spiky: globalization has changed the economic playing field, but hasn't leveled it. Atlantic Monthly, 296(3), 48-51.

Florida, R., \& Mellander, C. (2014). Rise of the startup city: the changing geography of the venture capital financed innovation. [Working Paper n. 377]. Centre of Excellence for Science and Innovation Studies.

Fritsch, M., Obschonka, M., \& Wyrwich, M. (2019). Historical roots of entrepreneurship-facilitating culture and innovation activity: An analysis for German regions. Article in preparation.

Glaeser, E. (2014). A world of cities: The causes and consequences of urbanization in poorer countries. Journal of the European Economic Association, 12(5), 1154-1199. doi:10.1111/jeea.12100

Greckhamer, T., Misangyi, V. F., \& Fiss, P. C. (2013). The two QCAs: From a small-N to a large-N set theoretic approach. In P. C. Fiss, B. Cambre, \& A. Marx (Eds.). Configurational theory and methods in organizational research (pp. 49-75). Bingley, England: Emerald Group.

Guerrero, M., Urbano, D., Fayolle, A., Klofsten, M., \& Mian, S. (2016). Entrepreneurial universities: Emerging models in the new social and economic landscape. Small Business Economics, 47(3), 551-563. doi:10.1007/s11187-016-9755-4

Isaksen, A. (2016). Cluster emergence: Combining pre-existing conditions and triggering factors. Entrepreneurship and Regional Development, 28(9-10), 704-723. doi:10.1080/08985626.2016.1239762
Isaksen, A., \& Trippl, M. (2017). Innovation in space: The mosaic of regional innovation patterns. Oxford Review of Economic Policy, 33(1), 122-140. doi:10.1093/oxrep/grwo35

Isenberg, D. (2010). The big idea: How to start an entrepreneurial revolution. Harvard Business Review, 88(6), 40-51.

Jucevicius, G., Juceviciene, R., Gaidelys, V., \& Kalman, A. (2016). The emerging innovation ecosystems and "valley of death": Towards the Combination of entrepreneurial and institutional approaches. Engineering Economics, 27(4), 430-438. doi:10.5755/j01. ee.27.4.14403

Kraus, S., Ribeiro-Soriano, D., \& Schüssler, M. (2018). Fuzzy-set qualitative comparative analysis (fsQCA) in entrepreneurship and innovation research: The rise of a method. International Entrepreneurship and ManagementJournal, 14(1), 15-33. doi:10.1007/ s11365-017-0461-8

Lerner, J. (2002). When bureaucrats meet entrepreneurs: The design of effective public venture capital programmes. The Economic Journal, 112 (477), F73-F84. doi:10.1111/1468-0297.00684

Martin, R., \& Sunley, P. (2003). Deconstructing clusters: Chaotic concept or policy panacea? Journal of Economic Geography, 3(1), 5-35. doi:10.1093/jeg/3.1.5

Mason, C., \& Brown, R. (2014). Entrepreneurial ecosystems and growth oriented entrepreneurship. Retrieved from http://lib.davender.com/ wp-content/uploads/2015/03/ Entrepreneurial-ecosystems-OECD.pdf

Motoyama, Y., \& Danley, B. (2012). An analysis of the geography of entrepreneurship: Understanding the geographic trends of Inc. 500 companies over thirty years at the State and Metropolitan levels. Kansas City, MO: Kauffman Foundation. Retrieved from https://www. kauffman.org/ /media/kauffman_org/research\%2oreports\%20 and\%20covers/2012/09/inc_geography.pdf

Neto, J., Farias Filho, J., \& Quelhas, O. (2014). Raising financial resources for small and medium enterprises: A multiple case study with Brazilian venture capital funds in the cities of Rio de Janeiro and São Paulo. International Journal of Innovation and Sustainable Development, 8(1), 77-91. doi:10.1504/ijisd.2014.059223

Nicotra, M., Romano, M., Giudice, M., \& Schillaci, C. (2018). The causal relation between entrepreneurial ecosystem and productive entrepreneurship: A measurement framework. Journal of Technology Transfer, 43(3), 640-673. doi:10.1007/s10961-017-9628-2

Patton, D., \& Kenney, M. (2010). The Role of the University in the Genesis and Evolution of Research-based Clusters. In D. Fornahl, S. Henn, and M.-P. Menzel (Eds.). Emerging Clusters: Theoretical, Empirical and Political Perspectives on the Initial Stage of Cluster Evolution (pp. 214-38). Cheltenham, UK: Edward Elgar.

Qian, H., \& Haynes, K. (2014). Beyond innovation: The Small Business Innovation Research program as entrepreneurship policy. Journal of Technology Transfer, 39(4), 524-543. doi:10.1007/s10961-013-9323-x

Radosevic, S., \& Yoruk, E. (2013). Entrepreneurial propensity of innovation systems: Theory, methodology and evidence. Research Policy, 42(5), 1015-1038. doi:10.1016/j.respol.2013.01.011 
Ragin Charles, C. (1987). Comparative method: Moving beyond qualitative and quantitative strategies. Berkeley, LA: University of California Press.

Ragin, C. (2006). Set relations in social research: Evaluating their consistency and coverage. Political Analysis, 14(3), 291-310. doi:10.1093/pan/mpjo19

Ragin, C. (2008). Redesigning social inquiry: Fuzzy sets and beyond. Chicago, IL: University of Chicago Press.

Schneider, C. Q., \& Wagemann, C. (2012). Set-theoretic methods for the social sciences: A guide to qualitative comparative analysis. Cambridge, UK: Cambridge University Press.

Spigel, B. (2017). The relational organization of entrepreneurial ecosystems. Entrepreneurship Theory and Practice, 41(1), 49-72. doi:10.1111/etap.12167

Stam, E. (2015). Entrepreneurial ecosystems and regional policy: A sympathetic critique. European Planning Studies, 23(9), 1759-1769. doi:10.1080/09654313.2015.1061484
Storper, M. (1995). The resurgence of regional economies, ten years later: The region as a nexus of untraded interdependencies. European Urban and Regional Studies, 2(3), 191-221. doi:10.1177/096977649500200301

Stuart, T., \& Sorenson, O. (2003). The geography of opportunity: Spatial heterogeneity in founding rates and the performance of biotechnology firms. Research Policy, 32(2), 229-253. doi:.1016/ So048-7333(02)00098-7

Wallsten, S. (2001). An empirical test of geographic knowledge spillovers using geographic information systems and firm-level data. Regional Science and Urban Economics, 31(5), 571-599.

World Economic Forum. (2014). Entrepreneurial ecosystems around the globe and early-stage company growth dynamics: The entrepreneur's perspective. Geneva, Switzerland: World Economic Forum.

World Economic Forum. (2018). These are the world's most innovative cities, and here"s why. Retrieved from https://www.weforum.org/ agenda/2018/01/worlds-most-innovative-cities-jll/ 